\title{
FAKTOR RISIKO PASCANATAL TERHADAP KEJADIAN STUNTING BADUTA USIA 6 - 18 BULAN DI PUSKESMAS MANTANGAI KABUPATEN KAPUAS PROVINSI KALIMANTAN TENGAH
}

\author{
Titik Istiningsih ${ }^{1}$, Eddy Fadlyana ${ }^{2}$, Ieva Baniasih Akbar ${ }^{3}$ \\ ${ }^{1}$ Poltekkes Kemenkes Palangka Raya \\ ${ }^{2}$ Departemen Anak RS Hasan Sadikin Bandung, \\ ${ }^{3}$ Direktorat Universitas Islam Bandung \\ Korespondensi: titikistiningsih1974@gmail.com
}

\begin{abstract}
Nutritional problem is a main problem in developing countries including Indonesia. Malnutrition in long term or chronic is the one of stunting cause. The high prevalence of stunting in Kapuas Regency is $42 \%$ in excess of the standards set by the WHO $20 \%$ which means that the stunting toddler in Kapuas Regency currently still above the limit of value is set by the World Health Organization. This research is aimed to Know Postnatal Risk Factors Affecting Stunting Events and the correlation between each variables and stunting event on 6-18 months old children at Mantangai Health center areain Kapuas districtin center Borneo.

This research design is cross sectional that observe 136 mothers who had 6-18 months old children as reseach samples at Mantangai Health Center area in Kapuas District taken by consecutive sampling. The collection of data was obtained through measurements of the infant body length to know stunting incidence data, interview for Status of exclusive breastfeeding data, infectious diseases history (Upper Respiratory Tract Infection), diarrhea history, weight history, maternal and child health services history and survey on the consumption by food frequency questionnaires method for intake of energy and protein history, then the data were processed and analyzed in a descriptive analytic used the chi-square test and multiple logistic regression test.

The result of research showed that the prevalence of stunting incidence was $40.4 \%$. The factors which had correlation to stunting were history of giving exclusive breastfeeding $p$-value $(p)=0.047$, energy intake $p=<0.001$, history of diarrhea $p=0.048$ and mothers 'visit to maternal and child health services $p=0.006$. The most dominant factor which had correlation to stunting were the Level of Energy Intake OR 15.990 and History of Diarrhea OR 3.130. Risk factors related to stunting events include the history of exclusive breastfeeding, energy nutrient intake, diarrhea history, and mothers' visit to maternal and child health services. Level of energy intake is the most dominant factor associated with stunting events.
\end{abstract}

Keywords: Stunting, exclusive breastfeeding, Energy intake, diarrhea, low birth weight. 


\begin{abstract}
ABSTRAK
Permasalahan gizi merupakan masalah utama di negara berkembang, termasuk di Indonesia. Kekurangan gizi kronis merupakan penyebab utama stunting. Prevalensi stunting Kabupaten Kapuas adalah sebesar 42\% melebihi -standar yang ditetapkan oleh WHO yaitu 20\% Tujuan penelitian ini ingin mengetahui faktor risiko Pascanatal yang berhubungan dengan kejadian stunting dan hubungan antara masing-masing variabel dengan kejadian stunting pada baduta usia 6-18 bulan di wilayah kerja puskesmas Mantangai kabupaten Kapuas provinsi Kalimantan Tengah.

Penelitian ini merupakan penelitian observasional analitik menggunakan desain potong lintang, dengan jumlah sampel penelitian 136 orang ibu yang memiliki Baduta berusia 6-18 bulan di wilayah kerja puskesmas Mantangai kabupaten Kapuas yang diambil secara consecutive sampling. Pengumpulan data di laksanakan pada bulan Maret-April 2019 dengan melakukan pengukuran panjang badan untuk data kejadian stunting, wawancara untuk data Status pemberian ASI ekslusif, riwayat penyakit ISPA, riwayat diare, riwayat berat badan lahir, dan riwayat kunjungan posyandu, serta survey konsumsi dengan metode food frequency questionnaires untuk data riwayat asupan energi dan protein, kemudian data diolah dan dianalisis secara deskriptif analitik menggunakan uji chi-square dan uji regresi logistik ganda

Hasil penelitian di tempat penelitian menunjukkan prevalensi kejadian stunting sebesar 40,4 \%. Faktor yang berhubungan dengan stunting diantaranya riwayat pemberian ASI ekslusif nilai $\mathrm{p}=0,047$, asupan energi nilai $\mathrm{p}=<0,001$, riwayat Diare nilai $\mathrm{p}=0,048$, kunjungan ibu baduta ke posyandu nilai $\mathrm{p}=0,006$. Faktor paling berhubungan dengan kejadian stunting adalah Tingkat Asupan Energi dengan OR=15,990 dan Riwayat Diare $\mathrm{OR}=3,130$. Faktor risiko yang berhubungan dengan kejadian stunting antara lain riwayat pemberian ASI ekslusif, asupan nutrisi energy, riwayat Diare, dan kunjungan ibu baduta ke posyandu. Tingkat asupan energi merupakan faktor paling dominan yang berhubungan dengan kejadian stunting
\end{abstract}

Kata Kunci : Stunting, ASI Ekslusif, Asupan Energi, Diare, BBLR.

\section{PENDAHULUAN}

Permasalahan gizi merupakan salah satu masalah utama pada negara berkembang. Masalah kurang gizi kronis stunting (pendek), dan wasting (Kurus) merupakan dua masalah kekurangan gizi yang menyita banyak perhatian dalam beberapa tahun terakhir. ${ }^{1}$ Kekurangan gizi pada anak mengakibatkan gangguan pertumbuhan (Growth faltering). Tahun 2017 terdapat 52 juta anak dibawah 5 tahun menderita kurus/wasted, 17 juta anak sangat kurus, 155 juta anak pendek (stunting), dan 41 juta mengalami kelebihan berat badan. Sekitar $45 \%$ kematian anak dibawah 5 tahun di sebabkan karena kekurangan gizi. Menurut data World Health Organization (WHO) stunting di negara ASEAN Indonesia mempunyai angka prevalensi yang cukup tinggi sebesar $37,2 \%$ dan prevalensi stunting negara 
Indonesia ini berada pada urutan nomor dua terbesar setelah Laos yang mempunyai angka prevalensi stunting $43,8 \% .^{2,3}$

Hasil Riskesdas 2018, provinsi Kalimantan Tengah trend kejadian stunting ditahun $2017 \quad 38,9 \%$ mengalami peningkatan ditahun 2018 menjadi $41.5 \%$. Kabupaten Kapuas dengan angka prevalensi stunting 42\%, di kecamatan Mantangai kabupaten Kapuas angka prevalensi balita stunting $32 \%$ dengan kriteria sangat pendek ada $54(25,4 \%)$ balita dan kriteria pendek ada $106(50 \%)$ balita, jumlah Baduta usia 6 - 18 bulan sebanyak 212 Baduta. $^{3}$

Pertumbuhan dan perkembangan anak dipengaruhi oleh faktor internal dan eksternal, salah satu faktor eksternal adalah faktor lingkungan. Lingkungan meliputi lingkungan biologis dan lingkungan fisik. Lingkungan biologis terdiri dari faktor gizi yang berhubungan dengan konsumsi makanan dan ASI ekslusif, kepekaan terhadap penyakit, penyakit kronis, faktor keluarga dan adat istiadat. Lingkungan fisik adalah kondisi geografis, sanitasi lingkungan yang memungkinkan terjadinya berbagai penyakit antara lain diare, cacingan dan infeksi saluran nafas. ${ }^{4}$ Tujuan penelitian ini adalah ingin mengetahui faktor risiko Pascanatal yang berhubungan dengan kejadian stunting dan hubungan antara masing-masing variable dengan kejadian stunting pada baduta usia 6-18 bulan di wilayah kerja puskesmas Mantangai kabupaten Kapuas provinsi Kalimantan Tengah.

\section{METODE}

Rancangan penelitian ini adalah observasional analitik, untuk menjawab apa sajakah faktor pascanatal yang berhubungan dengan kejadian stunting dengan desain penelitian cross sectional. Populasi dalam penelitian ini berjumlah $212 \mathrm{ibu}$ baduta Sampel dalam penelitian ini adalah ibu yang memiliki Baduta berusia 6-18 bulan yang terdaftar dalam buku Kohort KIA atau register posyandu, yang bertempat tinggal di wilayah kerja Puskesmas Mantangai Kabupaten Kapuas. Jumlah sampel berdasarkan rumus Binomunal Proporsi berjumlah sebanyak 136 baduta, penghitungan besar sampel pada setiap desa dilakukan secara proporsional sesuai proporsi di masingmasing desa yang berjumlah 15 desa dengan jumlah populasi baduta diwilayah kerja Puskesmas Mantangai sebesar 212 baduta. $^{7}$ 
Pengumpulan data laksanakan pada bulan Maret-April 2019 untuk variabel terikat panjang badan untuk data kejadian stunting dilakukan dengan cara mengukur panjang badan baduta menggunakan alat Baby Length board merk Seca 210, dengan terlebih dahulu dilakukan kalibrasi alat untuk memastikan keakuratan hasil ukur dengan cut off stunting yaitu -2 standar deviasi.(-2SD), Pengumpul data dalam penelitian ini adalah petugas Gizi Puskesmas Mantangai 2 orang untuk pengumpulan data panjang badan baduta dan wawancara survey konsumsi dengan metode food frequency questionnaire (FFQ) untuk variable asupan zat gizi MP-ASI. Peneliti sendiri melakukan wawancara untuk pengumpulan data variable ASI ekslusif ( $\geq 6$ bulan ASI saja), Riwayat penyakit ISPA (3 bulan terakhir), riwayat penyakit Diare(3 bulan sebelum wawancara), Riwayat berat badan lahir (<2500 gram), dan riwayat kunjungan ibu baduta ke Posyandu (> 9 kali kunjungan). Kemudian data diolah dan dianalisis secara deskriptif analitik menggunakan uji chi-square dengan kategori eklusif dan tidak ekslusif untuk variable ASI ekslusif, baik $(\geq 80 \%$ AKG) dan kurang ( $<80 \%$ AKG) untuk kategori asupan zat gizi MP-ASI, pernah dan tidak pernah menderita ISPA dalam 3 bulan terakhir untuk kategori Riwayat penyakit infeksi (ISPA), pernah dan tidak pernah menderita diare dalam 3 bulan terakhir untuk kategori riwayat Diare, BBLR dan normal untuk kategori riwayat BBL, rutin dan tidak rutin untuk kategori kunjungan ke posyandu. Uji regresi logistic ganda untuk menguji variable yang paling dominan berhubungan dengan kejadian stunting. Penelitian ini telah mendapatkan izin etik dari Komisi Etik Penelitian Universitas Bandung dengan surat omor 63/UN6.KEP/EC/2019.

\section{HASIL DAN PEMBAHASAN}

\section{Prevalensi Kejadian Stunting}

Tabel 1. Kejadian Stunting Baduta usia 6-18 Bulan di Puskesmas Mantangai, Kabupaten Kapuas, Kalimantan Tengah

\begin{tabular}{lcc}
\hline $\begin{array}{l}\text { Kejadian } \\
\text { Stunting }\end{array}$ & N & \% \\
\hline Normal & 81 & 59,6 \\
Stunting & 55 & 40,4 \\
\multicolumn{1}{c}{ Jumla } & 136 & 100.0 \\
\hline
\end{tabular}

Berdasarkan tabel diatas dapat dilihat prevalensi kejadian stunting baduta usia 6-18 bulan diwilayah puskesmas Mantangai kabupaten Kapuas sebesar $40,4 \%$. 
2. Analisis Bivariat Faktor risiko Pascanatal yang berhubungan dengan kejadian stunting Baduta usia 6-18 Bulan di Puskesmas Mantangai, Kabupaten Kapuas, Kalimantan Tengah

\begin{tabular}{|c|c|c|c|c|c|c|c|c|c|c|}
\hline \multirow{3}{*}{ Variabel Independen } & \multicolumn{4}{|c|}{ Kejadian Stunting } & \multirow{2}{*}{\multicolumn{2}{|c|}{ Total }} & \multirow[t]{3}{*}{$p$-value } & \multirow{3}{*}{$O R$} & \multicolumn{2}{|c|}{$95 \% C I$} \\
\hline & \multicolumn{2}{|c|}{ Tidak Stunting } & \multicolumn{2}{|c|}{ Stunting } & & & & & \multirow[t]{2}{*}{ lower } & \multirow[t]{2}{*}{ Upper } \\
\hline & $\mathrm{n}$ & $\%$ & $\mathrm{n}$ & $\%$ & $\mathrm{n}$ & $\%$ & & & & \\
\hline \multicolumn{11}{|c|}{ Pemberian ASI Ekslusif } \\
\hline - $\quad$ Ekslusif & 45 & 68,2 & 21 & 31,8 & 66 & 100 & 0,047 & 1,398 & 0,554 & 3,523 \\
\hline - $\quad$ Tidak Ekslusif & 36 & 51,4 & 34 & 48,6 & 70 & 100 & & & & \\
\hline \multicolumn{11}{|l|}{ Tingkat Asupan Energi } \\
\hline - Baik & 70 & 79,5 & 18 & 20,5 & 88 & 100 & 0,001 & 15,127 & 5,812 & 39,375 \\
\hline - $\quad$ Kurang & 11 & 22,9 & 37 & 77,1 & 48 & 100 & & & & \\
\hline \multicolumn{11}{|c|}{ Tingkat Asupan Protein } \\
\hline - Baik & 79 & 60,3 & 52 & 39,7 & 131 & 100 & 0,394 & 1,295 & 0,128 & 13,069 \\
\hline - $\quad$ Kurang & 2 & 40,0 & 3 & 60,0 & 5 & 100 & & & & \\
\hline \multicolumn{11}{|l|}{ Riwayat Penyakit ISPA } \\
\hline - $\quad$ TidakPernah & 41 & 58,6 & 29 & 41,4 & 70 & 100 & 0,809 & 0,614 & 0,247 & 1,525 \\
\hline - $\quad$ Pernah & 40 & 60,6 & 26 & 39,4 & 66 & 100 & & & & \\
\hline \multicolumn{11}{|l|}{ Riwayat Diare } \\
\hline - $\quad$ TidakPernah & 55 & & & 33,7 & 83 & 100 & 0,046 & 3,238 & 1,249 & 8,391 \\
\hline - Pernah & 26 & & & 50,9 & 53 & 100 & & & & \\
\hline \multicolumn{11}{|c|}{ Status BeratBadan Lahir } \\
\hline - Normal & 76 & 60,8 & 49 & 39,2 & 125 & 100 & 0,351 & 2,640 & 0,601 & 11,599 \\
\hline - $\quad$ BBLR & 5 & 45,5 & 6 & 54,5 & 11 & 100 & & & & \\
\hline \multicolumn{11}{|l|}{$\begin{array}{l}\text { Riwayat Kunjungan } \\
\text { Ke Posyandu }\end{array}$} \\
\hline - $\quad$ Rutin & 67 & 66,3 & 34 & 33,7 & 101 & 100 & 0,006 & 2,627 & 0,957 & 7,215 \\
\hline - $\quad$ TidakRutin & 14 & 40,0 & 21 & 60,0 & 35 & 100 & & & & \\
\hline Total & 81 & 59,6 & 55 & 40,4 & 136 & 100 & & & & \\
\hline
\end{tabular}


Berdasarkan tabel diatas dapat dilihat bahwa hasil secara statistik ASI ekslusif ( $\mathrm{p}=0,047)$, asupan energi ( $\mathrm{p}=0,001$ ), riwayat Diare $(\mathrm{p}=0,046)$, dan kunjungan ibu baduta ke posyandu $(\mathrm{p}=0,006)$ menunjukkan hubungan yang bermakna dan berpengaruh terhadap kejadian stunting. Dari tabel diatas juga dapat dilihat variabel yang tidak ada hubungan yang signifikan dengan kejadian stunting adalah asupan protein $(\mathrm{p}=0,394)$, riwayat penyakit ISPA $(\mathrm{p}=0,809)$, dan riwayat BBLR $(\mathrm{p}=0,351)$.

3. Faktor risiko yang Paling berhubungan dengan kejadian stunting Baduta usia 6-18 Bulan di Puskesmas Mantangai, Kabupaten Kapuas, Kalimantan Tengah.

Tabel 3. Analisis Multivariat

\begin{tabular}{|c|c|c|c|c|c|c|c|c|c|}
\hline & & \multirow[b]{2}{*}{ B } & \multirow[b]{2}{*}{ S.E. } & \multirow[b]{2}{*}{ Wald } & \multirow[b]{2}{*}{ df } & \multirow[b]{2}{*}{ Sig. } & \multirow[b]{2}{*}{$\operatorname{Exp}(B)$} & \multicolumn{2}{|c|}{ 95.0\% C.I.for EXP(B) } \\
\hline & & & & & & & & Lower & Upper \\
\hline \multirow[t]{8}{*}{ Step $1^{a}$} & Riwayat BBL & .971 & .755 & 1.653 & 1 & .199 & 2.640 & .601 & 11.599 \\
\hline & $\begin{array}{l}\text { Riwayat ASI } \\
\text { ekslusif }\end{array}$ & .335 & .472 & .504 & 1 & .478 & 1.398 & .554 & 3.523 \\
\hline & Riwayat Diare & 1.175 & .486 & 5.846 & 1 & .016 & 3.238 & 1.249 & 8.391 \\
\hline & Riwayat ISPA & -.488 & .464 & 1.104 & 1 & .293 & .614 & .247 & 1.525 \\
\hline & $\begin{array}{l}\text { Riwayat Kunj. } \\
\text { Posyandu }\end{array}$ & .966 & .515 & 3.512 & 1 & .061 & 2.627 & .957 & 7.215 \\
\hline & $\begin{array}{l}\text { Asupan } \\
\text { Energi }\end{array}$ & 2.716 & .488 & 30.976 & 1 & .001 & 15.127 & 5.812 & 39.375 \\
\hline & $\begin{array}{l}\text { Asupan } \\
\text { Protein }\end{array}$ & .259 & 1.179 & .048 & 1 & .826 & 1.295 & .128 & 13.069 \\
\hline & Constant & -8.144 & 2.104 & 14.988 & 1 & .000 & .000 & & \\
\hline
\end{tabular}


4. Faktor risiko yang Paling berhubungan dengan kejadian stunting Baduta usia 6-18 Bulan di Puskesmas Mantangai, Kabupaten Kapuas, Kalimantan Tengah.

Tabel 4. Analisis Logistik Ganda

\begin{tabular}{lcccc}
\hline \multicolumn{1}{c}{ Variabel } & Koefisien $\boldsymbol{\beta}$ & SE $\boldsymbol{\beta}$ & p-value & Adjusted OR (IK 95\%) \\
\hline Model Awal & & & & \\
- Status asi ekslusif & 0,223 & 0,462 & 0,629 & $1,250(0,506-3,092)$ \\
$-\quad$ Riwayat terkena diare & 1,082 & 0,467 & 0,021 & $2,952(1,181-7,376)$ \\
$-\quad \begin{array}{l}\text { Riwayat penimbangan } \\
\text { posyandu }\end{array}$ & 0,852 & 0,510 & 0,095 & $2,343(0,863-6,367)$ \\
$-\quad$ Tingkat asupan energi & 2,701 & 0,475 & 0,001 & $14,893(5,876-37,748)$ \\
& & & & \\
& & & 0,013 & $3,130(1,278-7,665)$ \\
Model Akhir & 1,141 & 0,457 & 0,001 & $15,990(6,387-40,035)$ \\
$-\quad$ Riwayat terkena diare & 2,772 & 0,468 & & \\
\hline
\end{tabular}


Berdasarkan hasil uji regresi logistic ganda diketahui terdapat hubungan yang bermakna antara tingkat asupan energy dengan kejadian stunting dengan nilai $\mathrm{POR}=15,990(6,387-$ 40,035) dan p-value 0,001 yang artinya anak yang tingkat asupan energinya kurang ( $<80 \%$ RDA) memiliki resiko 15,990 kali lebih tinggi mengalami stunting dibandingkan anak yang tingkat asupan energinya baik $(\geq 80 \%$ RDA). Tingkat Asupan Energi merupakan faktor paling dominan yang berhubungan dengan kejadian stunting. Selain tingkat asupan energy terlihat hubungan yang bermakna pada variable riwayat terkena diare dengan kejadian stunting, ditunjukkan dengan nilai POR $3,130(1,278-7,665)$ dan $\mathrm{p}$-value 0,013 yang artinya anak yang memiliki riwayat terkena diare memiliki resiko 3,130 kali lebih tinggi mengalami stunting dibandingkan anak yang tidak memiliki riwayat terkena diare.

Prevalensi stunting pada baduta usia 6 - 18 bulan diwilayah puskesmas Mantangai kabupaten Kapuas mencapai 40,4\%. Angka tersebut melebihi batas nilai non public health WHO yaitu sebesar 20\%, apabila dibedakan menurut perolehan nilai Z-score yang termasuk kategori stunting sebanyak 55 baduta $(40,4 \%)$ dan kategori normal sebanyak 81 baduta $(59,6 \%)$.

Berdasarkan hasil analisis statistik menunjukkan bahwa terdapat hubungan yang signifikan antara riwayat pemberian ASI tidak ekslusif dengan kejadian stunting dimana baduta dengan riwayat ASI tidak ekslusif mempunyai risiko mengalami stunting 2,024 kali lebih besar dibandingkan dengan baduta yang mendapatkan ASI ekslusif.

Berdasarkan hasil penelitian diperoleh data bahwa $48,6 \%$ baduta stunting tidak mendapatkan ASI secara Ekslusif. Hasil penelitian ini sesuai dengan hasil penelitian Simondon, dkk (2001) di Senegale yang menyatakan bahwa status menyusu juga merupakan faktor risiko terhadap kejadian stunting. Balita yang tidak diberikan ASI mempunyai risiko 2 kali lebih besar akan mengalami stunting dibandingkan balita yang diberikan ASI. ${ }^{8}$ Penelitian lain yang dilakukan di negara Ekuador yang menunjukkan bahwa 30\% dari anak stunting mendapatkan ASI kurang dari 6 bulan (tidak ekslusif). ${ }^{9}$

Dari 88 baduta yang tingkat asupan energinya baik sebagian besar tidak stunting yaitu sebanyak 70 baduta $(79,5 \%)$ sedangkan dari 48 baduta yang tingkat asupan energinya kurang 
sebagian besar stunting yaitu sebanyak 37 baduta $(77,1 \%)$. Hasil analisis menunjukkan bahwa terdapat hubungan yang bermakna antara tingkat asupan energi dengan kejadian stunting. Hasil penelitian ini didukung dengan hasil penelitian sebelumnya yang dilakukan oleh Lestari dkk yang mengutarakan bahwa anak dengan tingkat kecukupan energi yang rendah memiliki risiko 3,09 kali lebih besar terkena stunting dibandingkan dengan anak yang tingkat kecukupan energinya baik. $^{10}$ Hasil penelitian ini mengemukakan rendahnya asupan energi jika dilihat dari Recommended dietary Allowed (RDA) adalah $<80 \%$ baik dari kualitas dan kuantitasnya yang ditunjukkan hasil wawancara dengan kuesioner FFQ dimana total energi dari MP-ASI yang diberikan hanya mampu memenuhi kurang lebihnya $60 \%$ dari total kecukupan energi yang dibutuhkan yaitu $\mathrm{RDA} \geq 80 \%$. Hasil penelitian ini bertolak belakang dengan penelitian yang dilakukan oleh Aridiyah dkk di kecamatan Sedayu Bantul yang menyatakan bahwa tidak ada hubungan antara riwayat asupan energi dengan kejadian stunting $(\mathrm{p}>0,05){ }^{11,12}$

Berdasarkan hasil uji statistik Exact Fisher's didapatkan nilai p-value sebesar 0,394 >0,05 maka dapat disimpulkan bahwa tidak terdapat hubungan yang bermakna antara tingkat asupan protein dengan kejadian stunting. Pada 131 baduta yang tingkat asupan proteinnya baik sebagian besar tidak stunting yaitu sebanyak 79 baduta $(60,3 \%)$ sedangkan dari 5 baduta yang kategori asupan protein kurang sebagian besar stunting yaitu hanya 3 baduta $(60,0 \%)$.

Hasil penelitian ini sejalan dengan hasil penelitian di kecamatan Sedayu Bantul yang menyatakan bahwa tidak ada hubungan antara riwayat asupan protein dengan kejadian stunting ( $\mathrm{p}$ $>0,05)$. Secara teori Kekurangan gizi terjadi pada saat tubuh tidak memperoleh jumlah energi, protein, karbohidrat, lemak, vitamin dan mineral serta zat gizi lainnya dalam jumlah yang cukup yang diperlukan untuk mempertahankan organ dan jaringan tubuh agar tetap sehat dan berfungsi dengan baik. Asupan protein memiliki pengaruh terhadap pertumbuhan linier karena protein dalam tubuh berperan dalam pembentukan sel-sel dan jaringan baru. $^{9}$

Hasil penelitian ini tidak mendukung teori diatas, hal ini disebabkan karena pertumbuhan 
tinggi/panjang badan membutuhkan waktu yang lama, sehingga data asupan protein yang bersifat satu waktu tidak dapat menentukan hubungan asupan protein dengan kejadian stunting, walaupun rata-rata asupan protein yg dikonsumsi baduta tergolong kategori cukup $\mathrm{RDA} \geq 80 \%$ namun pada saat tubuh mengalami kekurangan energi maka pada kondisi ini protein akan berubah fungsi menjadi sumber energi sehingga protein tidak dapat memenuhi fungsinya sendiri. Kecukupan asupan protein baduta ini didukung dengan sumber protein hewani di daerah pedalaman Kalimantan Tengah ini yang sangat mudah didapat terutama sumber protein hewani dari ikan-ikan sungai yang masih berlimpah disana. Hasil penelitian ini sejalan dengan penelitian di Manado dengan subjek anak usia 1-3 tahun yang menunjukkan bahwa tidak ada hubungan yang signifikan antara asupan protein dengan kejadian stunting. ${ }^{13}$

Hasil penelitian ini menunjukkan bahwa tidak ada hubungan yang bermakna antara riwayat penyakit ISPA dengan kejadian stunting dengan nilai p-value sebesar 0,809 >0,05. Hasil penelitian ini berbeda dengan penilitian di Indonesia yang menganalisis hasil
RISKESDAS yang juga mengemukakan hasil yang berbeda yang menunjukkan peluang satu kali lebih besar pada anak dengan riwayat penyakit ISPA, kemungkinan akan menderita gizi buruk dan stunting. ${ }^{14}$

Penelitian lain yang dilakukan oleh Priyono dkk di puskesmas Randuagung kabupaten Lumajang yang menunjukkan bahwa sebagian besar anak 12-36 bulan dengan status gizi stunting memiliki penyakit infeksi dan dapat disimpulkan bahwa ada hubungan yang bermakna antara penyakit infeksi dengan kejadian stunting. ${ }^{15}$

Penyakit infeksi mempunyai efek terhadap status gizi untuk semua umur, khususnya pada anak. Infeksi juga mempunyai kontribusi terhadap defisiensi energi, protein dan gizi lain karena menurunnya nafsu makan sehingga asupan makanan berkurang. Dengan demikian perbaikan status gizi terbukti dapat mencegah anak terserang infeksi saluran pernafasan akut. ${ }^{16,17}$

Pada penelitian ini hasil yang didapatkan adalah penyakit ISPA bukan faktor penyebab terjadinya stunting. Hal ini kemungkinan dikarenakan baduta yang pernah mempunyai riwayat penyakit ISPA sebanyak 40 baduta $(60,6 \%)$ mempunyai status gizi tidak 
stunting, hal ini kemungkinan dikarenakan penyakit ISPA yang diderita hanya batuk pilek biasa yang tidak sampai mengarah ke penyakit Pneumonia, dan juga tidak sampai mengganggu pola makannya.

Hasil penelitian ini menunjukkan nilai p-value sebesar $0,046<0,05$, maka dapat disimpulkan bahwa terdapat hubungan yang bermakna antara baduta yang pernah menderita diare dengan kejadian stunting. Hasil penelitian ini sejalan dengan hasil penelitian yang dilakukan Berek TDK dkk, bahwa balita yang sering mengalami diare berpotensi menjadi penderita gizi kurang, kurus dan pendek, satu kali lebih besar dibandingkan anak balita normal atau anak balita dengan status gizi baik. ${ }^{18}$ Setiap episode diare dapat menyebabkan kekurangan gizi, sehingga bila episodenya berkepanjangan maka dampaknya terhadap pertumbuhan anak akan meningkat bila kondisi tersebut tidak segera ditangani dan diimbangi dengan pemberian asupan makanan yang adekuat, maka akan menyebabkan dehidrasi yang parah, malnutrisi dan gagal tumbuh. ${ }^{19}$

Hasil analisis statistik dengan uji Fisher Exact didapatkan nilai p-value sebesar 0,351>0,05 dapat disimpulkan bahwa tidak terdapat hubungan yang bermakna antara riwayat status berat badan lahir sampel dengan kejadian stunting. Dari 125 baduta yang status berat badan lahirnya normal sebagian besar tidak stunting yaitu sebanyak 76 baduta $(60,8 \%)$, sedangkan dari 11 baduta yang status berat badan lahirnya BBLR sebagian besar stunting yaitu sebanyak 6 baduta $(54,5 \%)$.

Hasil penelitian ini tidak sesuai dengan hasil penelitian yang dilakukan di Indramayu yang menunjukkan bahwa karakteristik bayi saat lahir mempengaruhi pola pertumbuhan post natal bayi. Bayi yang berukuran kecil untuk usia kehamilannya mengalami kegagalan tumbuh sejak dalam kandungan. Bayi prematur dengan berat lahir rendah, berat dan panjang badannya selain dipengaruhi oleh status gizi ibu, juga dipengaruhi oleh usia kehamilan. Bayi tersebut memiliki ukuran panjang, berat dan lingkar kepala yang kurang dari ukuran normal. Penelitian di Brazil dengan desian kohort melaporkan bahwa kelompok bayi lahir prematur memiliki risiko stunting saat usia 12 bulan sebesar 2,35 kali dan saat usia 24 bulan sebesar 2,30 kali. ${ }^{20,21}$ 
Pada bayi prematur proses pertumbuhan janin didalam rahim tidak mengalami gangguan, akan tetapi berat badan lahir bayi rendah karena bayi lahir sebelum waktunya dan berat badan sesuai masa gestasi. Pada bayi dengan Intra Uterine Growth Retardation (IUGR) terjadi kegagalan janin untuk mencapai potensi pertumbuhan secara penuh. $^{22}$

Dari 11 baduta yang memiliki riwayat berat badan lahir rendah 5 baduta $(45,5 \%)$ dengan status gizi normal dan 6 baduta $(54,5 \%)$ dengan status gizi stunting, semuanya dengan kondisi sehat secara klinis. Keadaan ini dapat disimpulkan bahwa stunting yang terjadi pada anak dengan riwayat BBLR dapat diminimalisir dengan menjaga kondisi kesehatan anak sehingga anak dapat melakukan pacu tumbuh untuk mengejar pertumbuhan normal sebelum umur 40 bulan. Dari 11 baduta yang memiliki riwayat berat badan lahir rendah semua disebabkan karena faktor prematuritas dan bukan karena faktor pertumbuhan janin terhambat.

Hasil penelitian ini menunjukkan nilai p-value sebesar $0,006<0,05$, maka dapat disimpulkan bahwa terdapat hubungan yang bermakna antara riwayat kunjungan baduta ke posyandu dengan kejadian stunting. Hasil penelitian ini sejalan dengan hasil penelitian yang dilakukan Welasasih, dkk menunjukkan ada hubungan bermakna antara kehadiran ke posyandu dengan status gizi balita stunting yaitu kelompok balita normal sebagian besar aktif hadir ke posyandu setiap bulan $(80,8 \%)$ dibandingkan dengan balita yang stunting. ${ }^{23}$

Keberadaaan posyandu sangat efektif untuk mendeteksi permasalahan gizi dan kesehatan. Keaktifan ibu balita membawa balitanya ke posyandu sangat besar pengaruhnya terhadap pemantauan status gizi. Kehadiran ke posyandu bisa menjadi indikator terjangkaunya pelayanan kesehatan pada balita. $^{24}$

Dalam penelitian ini keaktifan ibu baduta membawa anaknya ke posyandu ternyata sangat mempengaruhi tumbuh kembang anaknya. Dari 101 baduta yang mempunyai riwayat kunjungan ke posyandu rutin sebagian besar tidak stunting yaitu 67 baduta $(66,3 \%)$ sedangkan dari 35 baduta yang mempunyai riwayat kunjungan ke posyandu tidak rutin sebagian besar stunting yaitu sebanyak 21 baduta $(60,0 \%)$. Adanya pengaruh signifikan 
antara kunjungan ibu baduta ke posyandu dengan kejadian stunting berarti baduta yang rutin melakukan kunjungan ke posyandu setiap bulannya mempunyai peluang untuk tidak menjadi stunting.

\section{SIMPULAN}

Faktor risiko yang berhubungan dengan kejadian stunting antara lain riwayat pemberian ASI ekslusif, asupan nutrisi energy riwayat Diare, dan kunjungan ibu baduta ke posyandu. Sedangkan faktor risiko yang tidak berhungan dengan kejadian stunting diantaranya Asupan protein, riwayat penyakit ISPA, riwayat BBLR.. Tingkat Asupan Energi merupakan faktor paling dominan yang berhubungan dengan kejadian stunting.

\section{UCAPAN TERIMA KASIH}

Kepada Badan PPSDM Kementerian Kesehatan selaku penyandang dana dalam penelitian ini, Ketua Prodi S2 Kebidanan FK Unpad Dr. Hadi Susiarno, dr., $\operatorname{SpOG(K).,\quad M.Kes.,~}$ MH.Kes, pembimbing I Dr. Eddy Fadlyana, dr., $\quad \operatorname{SpA}(\mathrm{K}) ., \quad$ M.Kes, Pembimbing II Prof. Dr. Ieva Baniasih Akbar, dr., AIF, Dr. Gaga Irawan Nugraha, SpGK., M.Gizi. yang telah banyak membantu hingga selesainya penelitian ini.

\section{DAFTAR PUSTAKA}

1. Kikafunda JK Walker AF, Collett D, Tumwine JK. Risc factors for early childhood malnutrition in Uganda. Pediatrics. 1998;102:e45.

2. WHO. Global Health Observatory Data: Child Malnutrition. 2017.

3. TNP2K. 100 Kabupaten/Kota Prioritas untuk Intervensi Anak Kerdil (stunting): Ringkasan. Jakarta: Sekretariat wakil Presiden Republik Indonesia;2017.

4. Soejtiningsih, IG.N. Gde Ranuh. Tumbuh kembang anak; penyunting Suyono, JY.ed.2.Jakarta; EGC,2013. hlm595-609

5. Profil Kesehatan provinsi Kalimantan Tengah 2017. Dinas Kesehatan provinsi kalimantan Tengah

6. Hasil Pemantauan Status Gizi 2017. Dinas Kesehatan Provinsi Kalimantan Tengah.

7. Sastroasmoro S, Ismael S. Dasar-dasar metodologi penelitian klinis. Edisi ke5 Sagung Seto. Jakarta:2014

8. Mexitalia M. ASI sebagai pencegah malnutrisi pada bayi. Jakarta Badan penerbit Ikatan Dokter Anak Indonesia;2010

9. Simondon KB Sf, Costes R, Delaunay $\mathrm{V}$, Diall A. Breastfeeding is associated with improved growth in length, but now weight, in rural Senegalese toddlers 1-3. American journal Clinical Nutrition 2001;73:959-67.

10. Lestari W, Margawati A, Rahfiludin Z. Faktor risiko stunting pada anak umur 6-24 bulan di kecamatan penanggalan kota 
Subulussalam provinsi Aceh. Jurnal Gizi Indonesia (the Indonesian journal of Nutrition.

11. Aridiyah FO, Rohmawati N, Ririanty M. Faktor-faktor yang mempengaruhi kejadian stunting pada anak balita diwilayah pedesaan dan perkotaan (the factors Affectingstunting on Toddler in Rural and Urban Areas). Pustaka Kesehatan. 2015;3(1):163-70.

12. Maradesa E, Kapantow NH, Punuh MI. Hubungan antara asupan energi dan protein dengan status gizi anak usia 1-3 tahun di wilayah kerja puskesmas Wilantakan kecamatan Langowan. Kesmas. 2015;4(1)

13. Hidayat TS, Fuada N. Hubungan Sanitasi Lingkungan, Morbiditas dan Status Gizi Balita di Indonesia ( Relationship Between Environmental Sanitation, Morbidity and Nutrisional Status of Under-Five Children in Indonesia). Nutritition and Food Research.34(2).

14. Priyono DIP, Sulistiyani S, Ratnawati LY, Determinan Kejadian Stunting pada Anak Balita Usia 12-36 Bulan di Wilayah Kerja Puskesmas Randuagung Kabupaten Lumajang (Determinants of Stunting Among Children Aged 12-36 Months in Community Health Center of Randuagung, Lumajang Distric). Pustaka Kesehatan. 2015;3(2):349-55.

15. Rivera JA, Hotz C, Gonzalez-cossio T, Neufeld L, Garcia-Guerra A. The effect of micronutrien deficiencies on child growth. A Review of Result from comunity-based Supplementation Trial. J. Nutr. 2003;133:4010S-4020S.

16. Baqui AH, Zaman K, Persson LA, Arifeen SE, Yunus $M$, et al.
Simultaneus weekly supplementation of iron and zinc is associated with lower morbidity due to diarrhae and acute lower respiratory infection in Bangladesh infant. J Nutr. 2003;133:4150-4157

17. Berek TDK, Faizah Z, Purwaningsih E. Pola asuh ibu, kejadian diare dan pertumbuhan sampai 4 bulan pada bayi yang mengalami hambatan pertumbuhan dalam rahim. $M$ Med Indonesia. 2008;43(3):122-28.

18. Direktorat pencegahan penyakit Depkes RI. Informasi pengendalian penyakit dan penyehatan lingkungan. Jakarta; Departemen Kesehatan Republik Indonesia.

19. Kusharisupeni. Growth faltering pada bayi di Kabupaten Indramayu Jawa Barat. Makara Kesehatan. 2002; 6: 1-5

20. Santos IS, Matijasevich A, Dominingues MR, Barros AJ, Victoria $\mathrm{CG}$, Barros FC. Late preterm birth is a risk factor for growth falteringin early childhood: a cohort study. BMC pediatr. 2009;9:71-8

21. Maryunani A. Ilmu Kesehatan Anak dalam Kebidanan. Jakarta: Trans info Media; 2010

22. Welasasih BD, Wirjatmadi RB. Beberapa faktor yang berhubungan dengan status gizi stunting.2012 The IndonesianJournal of Public Health;2012: (3):99-104

23. Eko Putro Sandjojo. Buku Saku Desa dalam

Penanganan Stunting.Kementerian Desa, Pembangunan Daerah Tertinggal dan Transmigrasi; 2017 